\section{Nikola Fabris*}

\section{The History of Money in Montenegro'}

\begin{abstract}
The paper depicts the history of using money in Montenegro covering the period before the Christ until nowadays. Montenegro mostly used foreign currencies throughout its long history, these being Roman, Austro-Hungarian, Turkish, Venetian, and even the Napoleon (French gold coin) money. The first ideas for Montenegro's own money came from the Bishop Petar Petrovic Njegoš in the 19th century. The first Montenegrin money, the Perper, was minted in 1906. The King Nikola's Decree as of 11 April 1906 authorized the Ministry of Finance to mint the nickel and bronze coins. Silver and gold coins were minted later. The Perper disappeared from the scene with Montenegro's joining the Kingdom of Serbs, Croats and Slovenes, putting into circulation the Dinar, a currency of the newly established state. Montenegro, being a part of the Socialist Federal Republic of Yugoslavia, used the Dinar as its currency after World War II until 1999. Dual currency system consisting of the German Mark and the Dinar was introduced in late 1999, whereby the German Mark became the only legal tender in 2001. With the introduction of the Euro the German Mark was replaced and the Euro became the official means of payment.
\end{abstract}

KEY WORDS: Montenegro, Money, Perper, Euro, History.

JEL CLASSIFICATION: E51 and E40

\footnotetext{
${ }^{1}$ A part of this paper titled "The history of money in Montenegro from 1906-1918" was presented at the conference of the Faculty of Economics in Belgrade "The economic causes and consequences of the First World War".
}

\author{
${ }^{*}$ Central Bank of \\ Montenegro and Faculty \\ of Economics, Belgrade \\ University \\ E-mail: \\ nikola.fabris@cbcg.me
}




\section{Instead of Introduction - The History of Money in Montenegro}

Money has had a long history and it is difficult to determine reliably when it appeared first. It is usually considered that the first monetary system was created by Alexander the Great followed by the Roman Empire.

The history of money in Montenegro is a reflection of a turbulent history of the Balkans - various influences and interests, but also of a continuous striving of the Montenegrin people to be independent in choosing its own fate.

Various currencies had been in circulation in Montenegro throughout the centuries, starting from the Greek, Illyrian, Roman, Venetian, Serbian, Turkish money, and the like, which depended on who had a political or economic domination over Montenegro at the given time.

The oldest coin found in the territory of Montenegro dates back to the time before the Common Era, the period of the Illyrian queen Teuta who fled to Risan after the defeat from the Romans in 229 BCE (Šekularac 2007, p. 15). However, there are a lot of pieces of concrete evidence that copper and silver coins were minted in towns on the Montenegrin coast and its hinterland over the $2^{\text {nd }}$ and the $3^{\text {rd }}$ century BCE (Radunović 2007, p. 44). In the Illyrian times, money had been minted in other towns as well, primarily coastal towns which had their own money, and the Greek silver money had been in circulation in the inland. In the Middle Ages, different money circulated in Montenegro: Byzantine, Venetian, Hungarian, German, Turkish, Serbian, and the like.

There is evidence that numerous coins had been in circulation in Montenegro. Under the tutorship of Byzantium in the $11^{\text {th }}$ century CE, the mint in Kotor had produced coins, and it maintained its operation when the Serbian Tsar Dušan conquered Kotor. The mint continued producing coins after the town has been conquered by the Venetians who minted their money in Kotor until 1640 (Šekularac 2007, p. 17).

In the early $15^{\text {th }}$ century, after the town of Bar was conquered by the Turks, the mint was set up in this town. Throughout the Middle Ages coins were also minted in the coastal towns Ulcinj and Svac. The rulers of Zeta, the Balšići, also minted their coins in $14^{\text {th }}$ and early $15^{\text {th }}$ century and it is known that there were 11 types of money in circulation during their reign.

In spite of the fact that the coastal towns minted their own coins, the Byzantine gold coins were in circulation for a long time. An interesting fact is that the Byz- 
antine money was also called Perper, the name which was later given to the first Montenegrin state money. From the $16^{\text {th }}$ century, Venetian money was mostly in circulation in the coastal area, whereas the Dinar and the Dukat, and later the Turkish money Akcha circulated in the inland. In the $19^{\text {th }}$ century, Montenegro practically joined the Austrian-Hungarian monetary sovereignty for economically practical reasons, so the Monarchy's money stayed in circulation until the issuing of the first state money of Montenegro in the early $20^{\text {th }}$ century.

The first ideas for Montenegro's own money came from the Bishop Petar Petrović Njegoš in the $19^{\text {th }}$ century. It is assumed that he got an idea of minting the coins during his stay in Naples after meeting with Carl Rothschild, a banker and a financial magnate. There was an anecdote from that period saying that when Rothschild asked Njegos if coins have been minted in Montenegro, Njegoš answered: "If stone could be minted, I would have started minting them long ago" (Martinović 2007, p.227).

However, under the influence of Rothschild, a mould for minting coins was bought and brought to Cetinje (Montenegro's Capital at that time), in 1851. However, there have not been found any pieces of evidence that coins were actually minted, only a wax impression of a Perun coin, the currency named after the supreme Slavic deity. However, what the Bishop had failed to do was what the King Nikola did later on. ${ }^{2}$

\section{Money in Montenegro since the Beginning of XX Century until World War I}

The first European central banks were founded in the $17^{\text {th }}$ century through an evolutionary process as a result of wars and their pressures on state finances. The central bank has usually emerged by separating one of so called privileged banks which received the concession for issuing national money (Fabris 2006, p. 32). The majority of the first central banks were private institutions. Only 18 central banks existed in the world at the beginning of the $20^{\text {th }}$ century.

There was no central bank in the Principality and the Kingdom of Montenegro. Crnogorska Bank in Cetinje was established with the idea of becoming the cen-

2 The programme for minting Montenegrin money was prepared on the occasion of celebrating bicentenary of the Petrović Dynasty on the throne of Montenegro (1897), but this programme did not come to pass because the Austro-Hungarian Empire was not comfortable with the idea of Montenegro being monetary independent. 
tral bank, and the National Bank for the Principality of Montenegro has received the concession for issuing the national money. However, this has not been put into effect in practice. The instruments of the monetary authority remained in the hands of the state authorities.

The Austrian money - Fiorin was the main currency in Montenegro in the second half of the $19^{\text {th }}$ century. Fiorin was the official means of calculation until 1 May 1901 when Austrian Krone was introduced. At that time, Montenegro was an underdeveloped country with a dominant subsistence economy and small market surpluses. The most intensive original accumulation of capital was performed in trade. The crucial moment in the development of trade in goods and trade capital was the inclusion of the newly liberated cities and towns in the Montenegrin state, after the Congress of Berlin. In Podgorica, Nikšić and Bar, which had been until then a part of the Ottoman Empire, trade was substantially more developed than in the rest of Montenegro. Industrial capital started to develop only at the beginning of the $20^{\text {th }}$ century and it had a marginal role. On the eve of the World War I, there were only some larger industrial facilities and smaller industrial units. Larger facilities included a tobacco factory in Podgorica and two breweries in Nikšić. Moreover, there were two printing companies.

However, the development of trade in goods and the increase of the trade capital created a growing need for money. Accordingly, at the beginning of the twentieth century, banking capital appeared, i.e. modern forms of credit relations appeared, which gradually abolished usury. The first bank in the Principality of Montenegro was founded in 1901 as "Prva nikšićka štedionica". That same year, beyond the borders of the former Montenegro, Bokeška banka was founded in Kotor. Three years later, "Prva zetska štedionica" was established in Podgorica. In subsequent years another two banks were established, so that the issue of money and the monetary system had become increasingly important.

Austrian money circulated without any compensation as if Montenegro were a part of Austria-Hungary. In the political and economic circumstances at that time, the functioning of foreign currency had had a series of negative consequences. Consequently, at the end of the $19^{\text {th }}$ century, Montenegro sought to issue its own currency. Thus, the Minister of Foreign Affairs, Mr. Vuković, announced to the Austro-Hungarian envoy in Cetinje that Montenegro intended to mint gold and silver coins. In order to have equal circulation of Montenegrin money in the territory of the Austro-Hungary, he suggested the making of a Monetary Convention, which would help in resolving the issue of mutual circulation of money. 
Due to the absence of a response, the Minister of Finance, N. Matanović, was designated to negotiate with Austria-Hungary. It was suggested to mint the Montenegrin coins mostly of nickel and copper and silver coins and gold coins in smaller amounts. Although Austro-Hungary originally accepted this suggestion, it relatively quickly gave up, believing that such a large force has no need to sign a Monetary Convention with anyone, especially not with a small country such as Montenegro.

As G. Vuković (1985) pointed out in his memoirs, all that Austro-Hungarian government agreed was that: "Montenegro could mint its money in government mints at its own risk, for its account, at its expense and exclusively for its use. Austria will not officially ban the use Montenegrin money, but the state vaults and banks will not accept it under any conditions".

Since a large number of foreign currencies had circulated that time, like Krone, Talirs, Napoleons, Roubles, and the like, such system created numerous difficulties. Former Montenegrin Consul in Shkoder, Jovan Vaclik, proposed to Prince Nikola the minting of Montenegrin coins in 1902. He suggested that Montenegrin coins should be minted in the "Russian monetary castle in Petersburg", from the funds that Montenegro obtained as subsidies from Russia. Instead of paying subsidies in roubles, Vaclik suggested to mint Montenegrin coins gradually in four years in Petersburg and send them to Montenegro.

By the Decree of Prince Nikola of 11 April 1906 (Glas Crnogorca 1906, no. 15), the Ministry of Finance was authorised to mint nickel and bronze coins in the amount of 200.000 Krone (209 000 Krone was minted in the end). Even besides the idea that the coins should be minted in Paris and in Russian mints, they were ultimately minted in Vienna. Nickel and bronze coins were put into circulation on 28 August 1906. Simultaneously, the value of Montenegrin and Austrian coins was equalised, being 100 Para $=100$ Hellers, i.e. 1 Krone. Small Austrian coins had been replaced in this way and custom offices were ordered to replace Austrian money by 15 October 1906 and exclude it from circulation by 1 January 1907. However, due to the lack of small coins, Austrian money still remained in use in Montenegro. Therefore, new issue of coins was minted in 1908 in nominal amount of 110000 Krone. Total value of money in circulation amounted to 319000 Krone and it was insufficient. Gold coins of various countries were also present in circulation like U.S. Dollar, French Napoleon, German Mark, English Pound, Russian Rouble, Turkish Lira, and the like. In such conditions, monetary sovereignty of Montenegro was limited. 
Based on the initiative of the chief of the Ministry of Finance, M. Jovanović, the idea was to mint new currency - Perper. It was supposed to be minted as silver and gold coins. Originally, it was planned to mint it in Vienna, but due to the deterioration of political relations caused by the Annexation crisis, Montenegro turned to Serbia. Serbian national bank, through its financial institution, provided the loan and paid funds needed to a Parisian bank in Paris (Banque de Paris), since the French Minister of Foreign Affairs accepted the minting of coins. Therefore, Prince Nikola passed a Decree on the issue of silver coins on 4 May 1909. This Decree had also included for the first time the name of Montenegrin money - perper. Silver coins in the amount of 800000 Perpers were put in circulation which corresponded to the value of 800000 silver Krone.

The following issue of money occurred in March 1910, and gold coins were minted for the first time. The following coins in nominal value of 1.630 .000 Perpers were minted as follows: 1.030 .000 of gold and 600.000 of silver coins. Coins were minted in the Vienna mint this time due to poor quality of minting in the Parisian mint. In 1910, another issue of coins was done. Namely, on the occasion of celebrating fifty years of the rule of Prince Nikola, a special commemorative gold coin was minted which differed from the previous issue of Perpers. The commemorative gold coin was minted in Vienna and 1.000.000 Perpers were put in circulation.

However, it should be borne in mind that the state treasury did not benefit from the minting of coins, but it primarily had political implications, i.e. the reduction of dependence on Austro - Hungary. As M. Đurović pointed out, the first issue of gold coins experienced a loss of 7109.58 Perpers, and the second (commemorative) of 10064.55 Perpers (Đurović 1960, p. 68).

With a view to completing the monetary system, the Law on State Money of the Kingdom of Montenegro was passed in December 1910 and it came into effect at the beginning of 1911. The law prescribed that Montenegro "shall adopt gold currency for monetary traffic in its territory, which monetary unit shall be Perper". This law also determined the shape and signs on the reverse and obverse sides. The law prohibited circulation of foreign currencies in the territory of Montenegro, which was probably the major importance of this document.

This gave positive effects, i.e. it removed from circulation the Austrian silver and small nickel and copper coins, gave a positive financial effect for the state treasury, provided full confidence of citizens in domestic currency, reduced dependence on Austro-Hungary and strengthened political independence. 
Although Austro-Hungary did not recognise Montenegrin money, it however, de facto circulated also in the territory of Austro-Hungary, gold coins in particular. This was normal taking into consideration important trade relationships. Mutual trade created over time more favourable conditions for regulating monetary issues on the basis of reciprocity. The negotiations on Monetary Convention that have been going on over 15 years were completed on this basis in the middle of 1911, and the Convention entered into force on 21 September 1911. Based on this convention, the circulation of Perper was allowed in Austro-Hungary so that "gold coins were accepted at face value for customs payments in all AustrianHungarian customs offices, and for postal payments in Vienna, Trieste, Budapest, Zagreb, Rijeka and Sarajevo, as well as with all state treasuries authorised to accept gold coins" (Borozan 2007, p. 49). The Convention limited the circulation of Montenegrin money, in particular nickel and bronze coins, but the circulation of Austrian money in the territory of Montenegro on the same basis was also limited. Yet, this was a huge political success for Montenegro since the implementation of the reciprocity principle has been achieved, and Montenegrin and Austrian money were equalised.

However, the circumstances that occurred at that time such as foreign outflows, hoarding, and the like, influenced the permanent decline in Montenegro gold coins in trade. In 1912, only silver coins were minted. The law envisaged minting of silver coins in nominal value of 800.000 Perpers. However, only 300.000 Perpers were minted. The following table shows the amount of coins minted by years. ${ }^{3}$

Table 1: Minting of Montenegro's coins

\begin{tabular}{cc}
\hline Year & Value of minted coins \\
\hline 1906 & 209.000 \\
\hline 1908 & 110.000 \\
\hline 1909 & 800.000 \\
\hline 1910 & 2.630 .000 \\
\hline 1912 & 300.000 \\
\hline 1913 & 71.000 \\
\hline 1914 & 1.250 .000 \\
\hline
\end{tabular}

Source: Borozan, Dj. (2007), Minting of silver and gold perper and the issue of Monetary Convention between Montenegro and Austro-Hungary, Obod, Cetinje.

3 It should be pointed out that it was planned to mint coins in Paris in 1915. However, the war disabled its minting and certain copies from this issue were preserved nowadays with imprinted name ESSAI, which is a French word for trial. 
It is interesting to mention that money counterfeits appeared soon, in particular counterfeits of silver coins. The Minister of Finance gave the description of counterfeited money and how to recognize such money in the newspaper "Glas Crnogorca" (No. 13 for 1910). In addition, counterfeits of gold coins were also detected (denominations of 20 Perpers), of which counterfeit was excellent. They were made of gold of the same fineness as the original coins, and only instead of 6.78 grams they weighted 6.65 grams. The assumption is that these gold coins originated at a substantially later time and they were intended for collectors due to the extremely high price the Perper has in this market.

However, the political situation in the Balkans was considerably complicated. Montenegro was preparing for the First Balkan War, which significantly burdened public finances. Therefore, the Law on issuing treasury notes was passed in 1912. Pursuant to this law, treasury bills were issued as first Montenegrin paper money, which was guaranteed by the state up to their face value. It was envisaged that they should be in circulation only for a year. But due to the exhaustion of finance, this deadline was extended until 1 February 1914, and in practice the withdrawal of treasury notes was delayed for another several months. The second issue of treasury notes was performed in 1914, while the last one occurred in December 1915. All issues had a limited circulation period.

\section{Money in Montenegro between Two World Wars}

At the beginning of 1916, Austro-Hungary occupied Montenegro and assumed the governance of the monetary system. The disbursement of paper money was stopped and based on the decision of occupying authorities it remained in circulation, but an Austrian seal had to be imprinted on money. There are no data available on how much of the original issue of Perper was verified, but it was one third according to the assumption of P. Novaković (2006, p. 326). Worn paper banknotes were exchanged for new ones of 10 Perpers which issue was authorised by the Austrian-Hungarian military Governor General. This was the last money released in circulation based on the Law of the Kingdom of Montenegro but under the conditions set up by the occupying authorities.

With the emergence of the Kingdom of Serbs, Croats and Slovenes, the Perper disappeared. Perper coins were exchanged at a rate of 1 Dinar $=1$ Perper. Since no gold coins of the Kingdom of Serbs, Croats and Slovenes existed in that period, it was more cost-effective for the holders of Perper to negotiate the Perpers for gold rather than exchange them for Dinars. For Perper banknotes, the exchange rate was 5 Perper banknotes $=1$ Dinar banknote. It should be pointed out that 
the Perper was about $10 \%$ stronger than the Dinar before the unification. Perper banknotes were excluded from circulation from the middle of 1919. The Dinar had increasingly devalued over time and for instance, in 1921, 1 U.S. Dollar was exchanged for 100 Dinars, and only two years earlier the exchange rate was 1 U.S. Dollar $=10$ Dinars. This devalued the value of Perper even more.

Another discriminatory decision was passed in the middle of 1921, which envisaged that 1 Perper coin would be exchanged by 1 Dinar for those who had 5000 Perpers, while those who had over 5000 Perpers exchanged 2 Perpers for 1 Dinar. It should be also noted that the total money supply in Perpers was only $0.5 \%$ of money supply of the Kingdom of Serbs, Croats and Slovenes (Novaković 2006, p.334).

Therefore, it is not surprising that almost two thirds of Perper coins have never been replaced. It resulted in an insufficient amount of money in circulation and reflected negatively on the work of financial institutions, banks and savings banks in Montenegro and the rise in prices. In this way, the World War I had had negative effects on the development of the monetary and financial system in Montenegro. Poorer classes of citizens were mostly affected becoming even more impoverished by exchanging the Perper banknotes at a discriminatory exchange rate. This policy produced a lot of discontent in Montenegro, but it was obviously politically motivated.

The National Bank of the Kingdom of Serbs, Croats and Slovenes functioned as the central bank and it was renamed into the National Bank of the Kingdom of Yugoslavia in 1929. In the period from 1918 to 1941, the National Bank put into circulation 18 dinar banknotes and the corresponding quantity of coins. A large number of issued banknotes clearly indicated unstable monetary and general social and economic situation in Yugoslavia.

The collapse of the Kingdom of Yugoslavia announced also the collapse of the monetary and financial system. Monetary chaos was obvious during World War II as there were various monetary units in circulation (mostly the Italian Lira and small quantities of the Yugoslav Dinar, German Mark, Albanian Lek, and the like), as well as various money surrogates issued by the occupying authorities. Banca d'Italia took over the monetary authority. The exchange was often done by barter. 


\section{Money in Montenegro in period from the end of World War II until 1999}

Immediately before the end of World War II, the Presidency of AVNOJ passed the Law on Withdrawal and Replacement of Occupational Banknotes on 5 April 1945. New Yugoslav dinar banknotes were printed in the USSR and their introduction in circulation occurred in the period 20 April - 9 July 1945 when the Dinar of the Democratic Federal Yugoslavia became the only legal tender in the territory of the new state, including Montenegro.

The issuer of the new Yugoslav dinar was the state and banknotes did not include the signature of the governor of the central bank. The new central bank, the National Bank of the Democratic Federal Yugoslavia assumed the issuing function not sooner than on 10 January 1947 when a new series of banknotes was put in circulation.

After the disintegration of the SFRY, two former member republics - Montenegro and Serbia formed the Federal Republic of Yugoslavia (FRY) on 28 April 1992. In the new country, the monetary system was re-centralized, wherein the National Bank of Montenegro (NBM) lost its autonomy and became a regional office of the National Bank of Yugoslavia headquartered in Belgrade.

A high level of monetary and financial centralisation was established, which was easy to be manipulated and which enabled unbelievable misuses due to the nonexistence of any legal state and financial discipline, and this resulted in hyperinflation in the period $1992-1994$.

After the crash of the common market and simultaneous outbreaks of war in two former Yugoslav republics, the monthly inflation rate in Serbia and Montenegro was 50\% in February 1992, reaching 100\% in June that year. This percentage represents the general threshold that defines hyperinflation. At the end of 1993, inflation amounted to $3,508,091,786,746 \%$, which represents some of the highest hyperinflation rates in the world (Fabris, N. and others 2004).

The stabilisation programme of the Governor Avramovic from 1994 stopped the hyperinflation and brought a short-term period of relief. The price growth was stopped in seven days and the prices remained idle until the next year (Dimitrijević \& Fabris, 2012). However, soon after the replacement of the Governor Avramovic, the policy of fiscal domination over monetary policy continued. 


\section{Abandoning Dinar and Introducing German Mark and Euro}

At the beginning of 1999 the Montenegrin government started looking for a way to establish monetary independence of Montenegro. Starting from the practice of several years of both citizens and the business sector to perform transactions and save in German Marks, the Montenegrin government chose a dollarization model with the German Mark as the local national currency. ${ }^{4}$ Instead of the Dinar, the world's worst currency at the time, as estimated by S. Hanke (2000), Montenegro introduced a parallel currency system - one in which the German Mark was made the legal tender and allowed to freely float alongside Montenegro's other legal money, the Dinar (2 November 1999). The entire process was conducted swiftly and without any support or guidance of the IMF. At the time when the German Mark was introduced as the means of payment, the government was operating with a fiscal deficit of about 20\% of GDP (Hanke, 2000).

The Monetary Council ${ }^{5}$ governed the National Bank of Montenegro from the moment the German Mark was adopted until the establishment of the Central Bank of Montenegro. This body enacted numerous regulations which enabled the German Mark to be fully accepted as the means for payments, accounting, and hoarding.

Montenegro also met all theoretical requirements for a successful implementation of dollarization. It was a small, highly open country with experience of hyperinflation in the past, with almost no seigniorage income, with a great contribution of foreign trade with the EU, and substantial flexibility in the labour force (a great number of people were employed outside Montenegro).

The American emissary Mr Robert Gelbard, in his testimony before the United States Senate Foreign Relations Committee in 2000, described such a system and the policy of that time as the guiding light for the rest of the region (Dajković, 2004).

The introduction of dollarization, the situation in the monetary, financial and banking sectors of Montenegro began slowly but surely to show signs of increasing citizens' confidence in the new monetary regime. German Marks that had circulated in informal channels started to enter the legal flows. Therefore, it was

4 Regulation on the Use of the German Mark as the Means of Payment With a View to Protecting the Economic Interests of Montenegro (Official Gazette of the RM, no. 41/99 and 22/00)

5 Regulation on the Appointment of the Members of the Monetary Council (Official Gazette of RM no. 41/99, 45/99 and 39/00) 
estimated that a sufficient quantity of this currency was in circulation and there was no need to use the Dinar as the currency anymore. Thus, since January 2001 the German Mark (DEM) became the only legal tender, and since June 2002 the official means of payment has become the Euro.

When the German Mark and/or the Euro were introduced, numerous critics opposed such measure considering that it could have negative implications due to the loss of numerous economic policy instruments, money supply outflow as a consequence of high current account deficit, long-term recession, and the like. Nowadays, no individual or political party advocates the introduction of the national currency, which speaks in favour of good and prudent economic policy move.

Montenegro has had a number of benefits since the introduction of euro: price stability, return of the credibility of monetary policy, faster development of the financial system, interruption of fiscal deficit monetisation, substantial FDI inflows, and the like.

Currently, Montenegro is in the EU accession process and its objective is to address the issue of unilateral use of the Euro through negotiations with the EU and to become the euro area member shortly after joining the EU.

\section{Conclusion}

Different foreign currencies were in circulation in Montenegro until the beginning of the twentieth century. These were mainly currencies of various conquerors, as well as the most powerful economic forces at that time. The idea of minting the first Montenegrin money came from Njegoš, but the idea was realized by the King Nikola I, despite sharp opposition of the Austrian-Hungarian Monarchy.

Nickel and bronze coins of small value were minted first in 1906, while in 1909 silver Perpers were minted and a year later, in 1910, gold Perpers. Paper money was printed for the first time two years later.

The Kingdom of Serbs, Croats and Slovenes was created as a consequence of World War I. The Montenegrin money disappeared as a result of the birth of the new state. It was exchanged at discriminatory exchange rate so that coins were sold as gold. 
As a part of the former Yugoslavia, Montenegro used the Dinar as the means of payment after World War II. As a result of misuse of monetary policy, the Montenegrin Government passed a decision on introducing a dual currency system with the German Mark and the Dinar in 1999, whereby the German Mark was the only legal tender from 2001 until March 2002 when the Euro was introduced.

When the German Mark was introduced, a large number of critics considered that Montenegro should introduce its own currency as did the other former Yugoslav republics. Nowadays, there is a consensus in Montenegro regarding the use of the Euro and a concurrence that its introduction has brought numerous benefits to Montenegro. 


\section{References}

1. Borozan, Dj. (2007). Kovanje srebrnog i zlatnog perpera i pitanje monetarne konvencije izmedju Crne Gore iAustrougarske. Cetinje: Obod.

2. Dajković, A. (2004). A Model for the Balkans. Retrived from www.zmag. org/dajkovic.htm.

3. Dimitrijević, B. and Fabris, N. (2012). Ekonomska politika. Belgrade: Faculty of Economics.

4. Djurović, M. (1960). Crnogorske finansije 1860-1915. Cetinje: Obod.

5. Fabris, N. and others (2004). Economic Policy in Dollarized Economies with Special Review of Montenegro. Working paper no 1, Central Bank of Montenegro.

6. Fabris, N. (2006). Centralno bankarstvo u teoriji i praksi. Podgorica: Centralna Banka Crne Gore.

7. Fabris, N. (2008). Implication of Dollarization with a Special overview of Montenegro. Les Cahires de Recherche, no. 11, 3-31.

8. Fabris, N. (2014). The History of Money in Montenegro from 1906-1918. in The Economic Causes and Consequences of the First World war", ed. Vujačić, I, Ekonomski fakultet, Beograd.

9. Hanke, S. (2000). Some Reflections on Monetary Institutions and Exchange-Rate Regimes. Retrived from http:/www.cato.org/publications/ congressional-testimony/some-reflections-monetary-institutionsexchangerate-regimes.

10. Hanke, S. (2000). The Beauty of a Parallel Currency”. Retrived from www. cato.org/cgi/bin/scripts/printtech.cgi./dailys/01-14-00.html.

11. Službeni list Republike Crne Gore, brojevi 41/99, 45/99, 22/00 i 39/00.

12. Službeni organ Knjaževine Crne Gore. (1906). “Glas Crnogorca”. 15.april 1906, no. 15, Cetinje.

13. Martinović, B. D. (2007). "Planovi za kovanje crnogorskog novca”, in Novac u Crnoj Gori, ed. Radunovic et al., 223-233, Državni arhiv, Cetinje.

14. Novaković, P. (2006). "Perper”, in Novac u Crnoj Gori, ed. Radunovic et al., 337-352, Državni arhiv, Cetinje.

15. Radunović, S. (2007). “Antičke kovnice novca na teirotriji Crne Gore”, in Novac u Crnoj Gori, ed. Radunovic et al., 58-63, Državni arhiv, Cetinje.

16. Šekularac, B. (2007). "Razvoj crnogorske numizmatike”, in Novac u Crnoj Gori, ed. Radunovic et al., 11-25, Državni arhiv, Cetinje.

17. Vuković, G. (1985). Memoari. Cetinje: Obod. 